\title{
Metafizyk, poeta dewocyjny, satyryk? O poszukiwaniu dogodnej formuły
}

Katarzyna Wąsala 


\section{Metafizyk, poeta dewocyjny, satyryk? \\ O poszukiwaniu dogodnej formuly}

„Bohaterem książki jest Stanisław Grochowski, ksiądz” - tymi słowy zaczyna się bynajmniej nie „powieść z dziejów dawnych”, ale najnowsza monografia poety, którego uznawano za raczej drugorzędnego ${ }^{1}$. Postrzegano go jako przedstawiciela literatury mniej ambitnej intelektualnie (przecież to Mikołaj Sęp-Szarzyński z Sebastianem Grabowieckim dzierżą palmę pierwszeństwa), za to szerzej oddziałującej na kulturę społeczeństwa polskiego przełomu epok.

Decydującą rolę w ocenie autora Augusta wzbudzonego odegrał Czesław Hernas, sytuując Grochowskiego nie wśród polskich poetów metafizycznych, lecz w niższym kręgu pisarskim $^{2}$. Opinia ta wywołala ferment: już nie pierwszy po Kochanowskim poeta, nazwany Sancho Pansą metafizyków polskich! W jaki sposób dokonać podsumowania twórczości „wesołego księdza”, poety minorum gentium, wokół którego utworzyła się aura przypuszczeń i legenda poety prześladowanego?

„Dziś jest Grochowski poetą, którego się nie czyta” - zauważa Aleksandra Oszczęda, zastanawiając się nad jego miejscem w historii literatury polskiej, dotychczas niezbyt poczesnym. „Cóż jest człowiek? - jedno cień i para znikoma”, „pobożna miłość, szczęśliwe dzieciństwo, styl słodki i wytworny", ot, kilka haseł kojarzących się z omawianym twórcą, surowo ocenionym przez Hernasa: „Jego stylistyka barokowa jest tylko egzaminem rzemiosła, nie zaś wyrazem filozofii, nie angażuje, lecz bawi rebusową dziwnością"4

Poeta Wazów jest przykładem archeologii naukowego poznania, badaczka spogląda na Grochowskiego poprzez filtr epoki i pojmuje jego twórczość jako strukturę polifoniczną, tak określając swój punkt widzenia: „Upodobnienie dyskursu literaturoznawczego do literackiego spowolniło badania źródłowe nad Grochowskim i jego twórczością; odbijanie narracyjnych matryc $\mathrm{i}$ klisz sądów $\mathrm{z}$ rzadka tylko przerywane jest korygującą stan wiedzy

\footnotetext{
${ }^{1}$ Aleksandra Oszczęda, Poeta Wazów. Studia o okolicznościowej poezji Stanislawa Grochowskiego, Wydawnictwo Uniwersytetu Wrocławskiego, Wrocław 1999.

${ }^{2}$ Zob. C. Hernas, Barok, Warszawa 1997, s. 57. W syntezie tej pada stwierdzenie: „Nowszej monografii i wydania krytycznego brak. W druku opracowanie dotyczące okolicznościowej poezji politycznej" (s. 213).

${ }^{3}$ A. Oszczęda, op. cit., s. 122.

${ }^{4}$ C. Hernas, op. cit., s. 63.
} 
informacją" ${ }^{5}$. Zajmuje się zarówno zmiennymi kolejami popularności autora Pamiątki nagrobnej Samuela Gtowy, jak i jego kultem Kochanowskiego, pamiętając, iż uporządkowaniom aksjologicznym towarzyszą chronologiczne. Przede wszystkim jednak podejmuje próbę wyjaśnienia problemów związanych z tomem zbiorowym Grochowskiego.

W pierwszym rozdziale rozprawy autorka zajmuje się kompozycją Wierszy $i$ inszych pism co przebrańszych, dostrzegając prymarny podział przebiegający między tekstami religjnymi a świec$\mathrm{kimi}^{6}{ }_{\mathrm{i}}$ roztrząsając problemy edycji. Dokonuje wnikliwej analizy zasobu typograficznego (czcionek i ozdobników) tych krakowskich oficyn z początku XVII wieku, w których tłoczono osobne druki i zbiory pism poety. Omawia wydania pośrednie okolicznościowych broszur (powstałe najpierw jako druki osobne, potem umieszczone w tomie zbiorowym) tłoczone wtedy, gdy liczono się z ponownym zainteresowaniem odbiorców ${ }^{7}$. Powstają pytania: czy jest to wydanie zbiorowe, czy tez raczej klocek biblioteczny? (teoria zbioru z remanentów). Dlaczego wycofano drzeworyty, które ozdabiały edycje? Niestety, badaczka sama przyznaje, że są to hipotezy bez dowodów, dokonuje jednak przewartościowania sądu o aktywnym sympatyku dynastii Wazów: „Wiersze i insze pisma co przebrańsze to pierwszy w naszej literaturze różnogatunkowy wybór polskich poezji jednego autora, wydany za życia pisarza i prawdopodobnie z jego inicjatywy w celu stworzenia kanonu własnej twórczości”, ${ }^{8}$. Za niezwykle przydatną i cenną uznać należy bibliografię druków Grochowskiego, zamieszczoną jako podsumowanie rozdziału pierwszego.

Kolejnym ważnym zagadnieniem staje się udział poety-polityka w kreowaniu wizerunku dynastii Wazów, w argumentowaniu porządku sukcesyjnego i dynastycznego. Poruszając się między poezją, retoryką i polityką, Grochowski tworzy i propagandowy tryptyk, i apologię na zamówienie, a także satyrę na biskupów, nie zaniedbując żadnych sposobów propagandowego przekonywania (chociaż forsuje głównie koncepcję prowidencjalną).

Przywoływany tu kilkakrotnie Hernas zarzuca Grochowskiemu „spłycenie okolicznościowych form wypowiedzi”, a także to, iż „Gatunki okolicznościowe stały się po prostu elementem obyczajowości, uświetniały wydarzenie, były sposobem poszukiwania mecenasa, czego Grochowski był świadom" ". Oszczęda natomiast ukazuje ogromny talent księdza-satyryka, który był autorem zarówno laudacji osób dostojnych (wzorowanych na psalmach pochwalnych), jak i przynajmniej dwóch wersji paszkwilu Babie koło, czym sobie ponoć zasłużył na niełaskę zwierzchników kościelnych. Zasłużył się również przekładem pierwszej księgi Floridorum Pontanusa ${ }^{10}$, a także przeszczepiał na grunt polski włoskie madrygały wojenne.

\footnotetext{
5 A. Oszczęda, op. cit., s. 131.

6 Zob. ibid., s. 34.

7 Zob. ibid., s. 17.

${ }^{8}$ Ibid., s. 59.

9 C. Hernas, op. cit., s. 51.

${ }^{10}$ Opracowane przez Justynę Dąbkowska jako Wirydarz, abo Kwiatki rłmów duchownych o dziecięciu Panu Jezusie w serii Biblioteka Pisarzy Staropolskich, Warszawa 1997.
} 
Mimo wpływów włoskich liryka okolicznościowa Grochowskiego stale odnawia związki z twórczością największego z naszych poetów renesansowych, a nasycenie tekstu komponentami tradycji czarnoleskiej jest stale widoczne. August wzbudzony to przecież pochwała złotych lat polskiego renesansu, która zarazem jest „tekstem długiego trwania w przeciwieństwie do krótkotrwałych utworów okolicznościowych i dokumentem nowej parenetyki tworzącej osobowy ideał czlowieka rycerskiego przeznaczony dla drobnej i średniej szlachty" ${ }^{11}$.

Grochowski, który należy dziś do pisarzy niezbyt cenionych i rzadko drukowanych, w wieku XVII był jednym z nielicznych autorów, których teksty funkcjonowały w szerokim obiegu czytelniczym, i pierwszym, którego pisma zebrane wydano. „Dbały o druk zarówno drobnych, ulotnych broszur politycznych, jak i ponad 600-stronicowego zbioru wierszy, jest kontynuatorem renesansowego zachwytu drukiem, postawy wobec własnej twórczości manifestującej się w dialogu z publicznością, toczonym za pośrednictwem drukowanych dzieł"12.

Ostatnie studium zostało poświęcone historii badań nad Grochowskim. Stawiając historyków literatury w roli czytelników, Aleksandra Oszczęda zastanawia się również nad tym, które utwory Grochowskiego czytano najchętniej i umieszczano w kancjonałach i antologiach. Całości „studiów o poezji okolicznościowej” dopełniają dolączone teksty analizowanych wcześniej wierszy. Stanowi to niezaprzeczalny atut rzeczonej rozprawy, wydanej w starannej szacie edytorskiej.

Katarzyna Wasala

\section{Mieczysław Klimowicz}

Polsko-niemieckie pogranicza literackie $w$ XVIII wieku. Problemy uczestnictwa $w$ dwu kulturach, Ossolineum, Wrocław 1998, ss. 235.

Znaczenie najnowszej książki Mieczysława Klimowicza dla naszej wiedzy o polskim oświeceniu polega po pierwsze na uświadomieniu czytelnikowi, jak dalece pojęcie „Rzeczpospolita Obojga Narodów" jest nieadekwatne w odniesieniu do spraw kultury w wieku XVIII. Akcentując wagę unii politycznej między Koroną a Litwą marginalizuje ono rolę, jaką również i w tym stuleciu w życiu umysłowym Polski odgrywały inne grupy etniczne, przede wszystkim Niemcy, i to niezależnie od tego, czy byli oni obywatelami Rzeczypospolitej, czy też żyli i działali poza jej granicami. Przywołana tu problematyka pluralizmu kulturowego pozostaje do tej pory na ogól na marginesie badań nad polskim oświeceniem. Mówiąc o dokonaniach epoki w zakresie literatury, sztuk wizualnych czy cywilizacji technicznej w kontekście kontaktów $\mathrm{z}$ innymi narodami, niemal wyłącznie interesowano się, chociaż

\footnotetext{
" A. Oszczęda, op. cit., s. 79.

12 Ibid., s.103.
} 